\title{
Quantitative trait loci associated with soft wheat quality in a cross of good by moderate quality parents
}

\author{
Gioconda Garcia-Santamaria ${ }^{\text {Corresp.. }}{ }^{1}$, Duc Hua ${ }^{2}{ }^{\text {, }}$ Clay Sneller ${ }^{3}$ \\ 1 Faculty of Agricultural Sciences, Central University of Ecuador, Quito, Pichincha, Ecuador \\ 2 Department Horticulture and Crop Sciences., Ohio State University- Wooster, Wooster, Ohio, United States of America \\ Department of Horticulture and Crop Sciences, Ohio State University-Wooster, Wooster, Ohio, United States of America \\ Corresponding Author: Gioconda Garcia-Santamaria \\ Email address: gmgarcia@uce.edu.ec
}

Information on the genetic control of the quality traits of soft wheat (Triticum aestivum) is essential for breeding. Our objective was to identify QTL associated with end-use quality. We developed 150 F4derived lines from a cross of Pioneer 26R46 $\times$ SS550 and tested them in four environments. We measured flour yield (FY), softness equivalent (SE), test weight (TW), flour protein content (FP), alkaline water retention capacity (AWRC), and solvent retention capacity (SRC) of water (WA), lactic acid (LA), sucrose (SU), sodium carbonate (SO). Parents differed for nine traits, transgressive segregants were noted, and heritability was high (0.67 to 0.90$)$ for all traits. We detected QTL distributed on eight genomic regions. The QTL with the greatest effects were located on chromosome $1 \mathrm{~A}, 1 \mathrm{~B}$, and $6 \mathrm{~B}$ with each affecting at least five of ten quality traits. Pioneer 26R46 is one of the best quality soft wheats. The large-effect QTL on 1A novel and accounted for much of the variation for AWRC $\left(r^{2}=0.26\right)$, SO $(0.26)$ and SE (0.25), and FY (0.15) and may explain why Pioneer $26 R 46$ has such superior quality. All alleles that increased a trait came from the parent with the highest trait value. This suggests that in any population that marker-assisted selection for these quality traits could be conducted by simply selecting for the alleles at key loci from the parent with the best phenotype without prior mapping. 
1 Quantitative trait loci associated with soft wheat quality in a cross of good by moderate quality parents

3 Gioconda Garcia-Santamaria ${ }^{1}$, Duc Hua ${ }^{2}$, Clay Sneller ${ }^{3}$

$4 \quad{ }^{1}$ Faculty of Agricultural Sciences. Central University of Ecuador. Quito, Ecuador

$5 \quad{ }^{2}$ Department of Horticulture and Crop Sciences. Ohio State University-Wooster. Wooster, Ohio.

6 United States of America.

$7 \quad{ }^{3}$ Department of Horticulture and Crop Sciences. Ohio State University-Wooster. Wooster, Ohio.

8 United States of America.

9 “*Corresponding author” gmgarcia@uce.edu.ec phone: 2905669

10 orcid.org/0000-0003-3730-1520 


\section{ABSTRACT}

Information on the genetic control of the quality traits of soft wheat (Triticum aestivum) is

13 essential for breeding. Our objective was to identify QTL associated with end-use quality. We

14 developed 150 F4-derived lines from a cross of Pioneer 26R46 $\times$ SS550 and tested them in four

15 environments. We measured flour yield (FY), softness equivalent (SE), test weight (TW), flour

16 protein content (FP), alkaline water retention capacity (AWRC), and solvent retention capacity

17 (SRC) of water (WA), lactic acid (LA), sucrose (SU), sodium carbonate (SO). Parents differed

18 for nine traits, transgressive segregants were noted, and heritability was high ( 0.67 to 0.90$)$ for all

19 traits. We detected QTL distributed on eight genomic regions. The QTL with the greatest effects

20 were located on chromosome $1 \mathrm{~A}, 1 \mathrm{~B}$, and $6 \mathrm{~B}$ with each affecting at least five of ten quality traits.

21 Pioneer 26R46 is one of the best quality soft wheats. The large-effect QTL on 1A novel and

22 accounted for much of the variation for AWRC $\left(\mathrm{r}^{2}=0.26\right)$, SO (0.26) and SE (0.25), and FY (0.15)

23 and may explain why Pioneer 26R46 has such superior quality. All alleles that increased a trait

24 came from the parent with the highest trait value. This suggests that in any population that

25 marker-assisted selection for these quality traits could be conducted by simply selecting for the

26 alleles at key loci from the parent with the best phenotype without prior mapping. 
INTRODUCTION

Soft red winter wheat (SRWW) (Triticum aestivum L. em. Thell) end-use quality is

29 determined by flour quality requirements related to grain characteristics and flour functionality.

30 Functional flour for US biscuit industry should have a low water absorption capacity, high gluten

31 strength, low damaged starch and arabinoxylans whereas for bread making needs high water

32 absorption capacity, good gluten strength and high damaged starch and arabinoxylans or the so

33 called water extractable arabinoxylans (Slade \& Levine, 1994; Kweon et al., 2011). The starch

34 granules of soft wheat mill easier than those of hard wheat resulting in intact granules that absorb

35 less water (Igrejas et al., 2002). Good soft wheat produces high break flour yields with fine

36 particle with minimal damaged starch, and low arabinoxylan content so that the flour absorbs less

37 water. The reduced water absorption capacity of soft wheat flour contributes to its functionality

38 (Finney \& Baines, 1999; Souza et al., 2002; Kweon et al., 2011). To fully characterize flour

39 quality, it is important to evaluate flour protein (FP) and gluten functionality determined by

40 specific combinations of high molecular weight subunits of glutenins associated with gluten

41 strength (Igrejas et al., 2002).

42 Evaluation of soft wheat flour functionality is done by prediction tests. By combining

43 alkaline water retention capacity (AWRC) and four solvent retention capacity (SRC)

44 measurements, it is possible to determine the water absorption capacity of the flour as well as

45 individual functional components that underlie it and determine flour functionality (Slade \&

46 Levine, 1994; Gaines, 2000; Kweon et al., 2011). Specifically, by the sodium carbonate (SO)

47 SRC assesses the effect of damaged starch, the sucrose (SU) SRC assesses the effect of

48 arabinoxylans, the lactic acid (LA) assesses the effect of glutenin characteristics, and the water

49 (WA) assesses the overall water absorption capacity (Slade \& Levine, 1994), making it easier to

50 identify superior lines (Souza et al., 2002). The LA is a particularly useful measure as it assesses

51 gluten strength and can be adjusted for the quantity of protein (adjusted LA, or ADLA) so that it 
52 relates to protein quality (Gaines, 2000). Soft wheat with high LA values have strong gluten and

53 are suited for crackers and flat bread, while those with low LA have weaker gluten and are best

54 suited for pastries (Guttieri et al., 2001). The LA has particular relevance to soft wheat as

55 identity-preserved programs for strong-gluten soft red winter wheat exist in the eastern US

56 (Kweon et al., 2011).

57 In addition to flour functionality, milling traits are an important component of soft wheat

58 quality. Flour yield (FY) is a measure of straight grade flour from commercial mills with FY

$59>72 \%$ being preferred. Softness equivalent (SE) and test weight (TW) are also considered is

60 assessing soft wheat quality (Finney \& Andrews, 1986; Marshall et al., 1986; Finney \& Baines,

61 1999).

62 Allelic variation at loci encoding high molecular weight and low molecular weight

63 glutenin subunits has a major influence on gluten strength (Payne et al., 1981) (Gupta et al., 1989;

64 Rpusset et al., 1992; Nieto-Taladriz et al., 1994; Graybosch et al., 1996). Glutenin subunits

$65 G l u D x 5+G l u D y 10$ confer strong dough mixing characteristics and good bread-making quality,

66 while GluDx2 +GluDy12 are associated with weak dough and poor bread-making quality (Payne

67 et al., 1981; Hamer et al., 1992; Manley et al., 1992). Genes encoding glutenin subunits have

68 been mapped to the short and long arms of homoeologous chromosomes 1A, 1B, and 1D

69 (Harberdt et al., 1986) and allele-specific primers can be used as markers to differentiate these

70 alleles (D'Ovidio \& Anderson, 1994; Gale et al., 2003). Loci associated with water absorption

71 capacity have been identified in hard wheat (Mansur et al., 1990). Similarly, loci influencing FP,

72 kernel hardness, and TW have been mapped (Mattern et al., 1973; Blanco et al., 1996; Sourdille

73 et al., 1996: Prasad et al., 1999; Perretant et al., 2000; Galande et al., 2001; Prasad et al., 2003;

74 Turner et al., 2004).

75 Previous correlation studies of soft wheat quality traits have already shown that flour 76 damaged starch and arabinoxylan levels may be controlled by common genetic factors (Guttieri 
77 \& Souza, 2003; Smith et al., 2011; Cabrera et al., 2015; Hoffstetter et al., 2016). Earlier studies

78 about the heritability of SRCs in soft wheat have shown high heritability (Guttieri \& Souza,

79 2003; Smith et al., 2011; Cabrera et al., 2015; Hoffstetter et al., 2016). Common QTLs for

80 AWRC and damaged starch were observed in a hard $\mathrm{x}$ soft population on chromosome 4DL

81 (Campbell et al., 2001). Smith et al. (2011) and Cabrera et al. (2015) reported large effect QTL in

82 SRWW for milling and baking quality associated with translocations on chromosomes $1 \mathrm{~B}$ and $2 \mathrm{~B}$

83 and that these effects were repeatable over populations. Cabrera et al. (2015) also presented

84 evidence that QTL located on 1B and 2B affected SRWW quality even in the absence of the

85 translocations. Hoffstetter et al. (2016) conducted an association analysis in SRWW and reported

86 nine QTL for SRWW quality traits though the $r^{2}$ values were small (0.018 to 0.036$)$.

87 SRC prediction tests are an efficient tool for predicting flour functionality. Knowledge

88 about the underlying genetic control of these specific traits is necessary to supplement phenotypic

89 selection. Identifying areas of the soft wheat genome harboring QTLs for functional end-use

90 quality will assist in breeding and in understanding the genetic components of this suite of traits.

91 The main objective of this study was to identify QTLs related to quality traits in SRWW,

92 and to broaden our knowledge of the underlying genetics of quality end-use traits. 
93 MATERIALS AND METHODS

\section{Plant Materials}

95 We used a recombinant inbred line (RIL) population consisting of $150 \mathrm{~F}_{4}$-derived lines

96 generated through single-seed descent from a cross of soft winter wheat lines Pioneer 26R46 by

97 SS550. Parents and $\mathrm{F}_{4: 5}$ were grown in one replicate in an augmented block design in 2002, $\mathrm{F}_{4: 6}$ in

98 two replicates during 2003, and $F_{4: 7}$ in an augmented design in 2004 at the Ohio Agricultural

99 Research and Developing Center (OARDC) in Wooster, OH, USA. Standard fertilizer

100 applications were used with $150 \mathrm{~kg} \mathrm{ha}^{-1}$ of 18-46-0 (N-P-K) applied before planting and $65 \mathrm{~kg} \mathrm{ha}^{-}$

$101{ }^{1}$ of $\mathrm{N}$ applied in the spring. The plot size was a single $3 \mathrm{~m}$ row with $0.3 \mathrm{~m}$ space between rows.

102 Replicates in 2003 were considered as environments (2003A and 2003B).

103 Parents were chosen based on the quality data report of the Soft Wheat Quality

104 Laboratory (SWQL) of The United States Department of Agricultural Research Service (USDA,

105 ARS) at Wooster, OH. At the time, Pioneer 26R46 was the highest quality ranking soft wheat

106 cultivar due to its low water absorption capacity, high FY, large cookie diameter, high gluten

107 strength, and GluDx5 + GluDy10 alleles. The parent SS550 (VA96W-247) has moderate quality,

108 low FP, very soft texture, moderate gluten strength, and high AWRC.

109 Quality Determination

110 Quality analysis was conducted in the USDA SWQL of Wooster, OH, USA on the single

111 replication in 2002, separate grain samples from each replication in 2003 (A y B) and a single

112 grain sample pooled from both reps in 2004. The reason for this sampling is that in 2002 there

113 was only enough grain for one plot; in 2003 we planted two plots though the analysis indicated

114 there was little error within a field. Thus in 2004 grain from the two reps was pooled to form one

115 sample that was assayed. Grain from the parents and RILs was threshed, cleaned, tempered to 14

$116 \%$ moisture, and milled in a Quadrumat junior mill (American Association of Cereal Chemists

117 (AACC) method 26-50) to determine milling and flour quality characteristics. Milling traits (FY, 
118 TW, and SE), FP, and AWRC were measured using standard procedures as described by AACC

119 methods 39-11 and 56-10 (AACC, 1983). The SRCs were measured according to AACC method

120 56-11 (Gaines, 2000).

121 Statistical Analysis of Phenotypic Traits

122 Variation in the parents was determined using analysis of variance (ANOVA). Phenotypic

123 data from parents and RILs for ten quality traits from four environments (2002, 2003A, 2003B,

124 and 2004) was analyzed using Proc GLM of Statistical Analysis System (SAS) v.9.1 (SAS

125 Institute, 1994) using the model:

$$
y_{i j}=u+g_{i}+e_{j}+\text { error } i j
$$

126 where $g_{i}$ is the effect of the $i^{\text {th }}$ genotype and $e_{j}$ is the effect of the $j^{\text {th }}$ environment. Genotype and

127 environment effects were considered random. This analysis was used to estimate an LSD

$128(\mathrm{P}<0.05)$ to test whether RILs differed from their parents as well as other comparisons. We

129 estimate variance components with PROC MIXED (SAS v9.1) [ CITATION SAS94 \1 12298 ]

130 using just RIL data to test the significance of RIL effects. Best linear unbiased predictors were

131 obtained for each RIL and were used in mapping and in for correlation analysis for the ten quality

132 parameters. The RIL effects were highly correlated between environments so data were combined

133 over environments for analysis. Entry-mean heritability $(\mathrm{H})$ was calculated using only RIL data 134 as:

$$
H=\sigma_{g}^{2} / \sigma_{g+}^{2}\left(\sigma_{\text {error }}^{2} / 4\right)
$$

136 where $\sigma_{g}^{2}$ and $\sigma_{\text {error }}^{2}$ are the genetic and error variance, respectively.

137 Linkage Map

138 Parents were screened for polymorphism using 700 Single Sequence Repeats (SSR)

139 primers previously published (Röder et al., 1998; Cregan et al., 2001; Gupta et al., 2002). The 
140 population was genotyped with 107 SSR markers that were polymorphic between the parents.

141 The GluDx5 allele-specific primer developed by Gale (Gale et al., 2003) was also included.

142 Genetic linkage maps were constructed with JoinMap 3.0 (Van Ooijen \& Voorrips, 2001)

143 Grouping of similar loci was based upon the test for independence and was done at several

144 significance levels of the logarithm of the odds (LOD) scores. Linkage groups were constructed

145 at a probability of 0.0001 followed by the 'ripple' command to refine the order of markers and

146 place the marker loci in a linkage group.

147 QTL Analysis

148 QTL positions in the genome were calculated using MapQTL 4.0 (Van Ooijen, 2002) with

149 composite interval mapping with the maximum likelihood approach. The components $(Q)$ of a

150 mixture depending on the QTL genotype, which would be $Q=3$ in the case of the RIL. The

151 component distributions are assumed to be normal, and the Haldane mapping function was used,

152 which assumes that recombination events are mutually independent. QTLs are calculated under

153 the alternative hypothesis that a single QTL is segregating. The likelihood (LOD) is calculated at

154 each iteration, and QTLs were considered to be those regions having LOD $\geq 2.8$. The functional

155 tolerance value and the maximum number of interactions used were 200. 
156 RESULTS

\section{Quality testing}

158 The two parents differed significantly nine traits but not for FP (Table 1). The RILs

159 exhibited a continuous distribution and transgressive segregants were observed for all traits (Fig.

160 1, 2, 3, 4). Minimum and maximum means of RILs exceeded the means of the two parental lines,

161 indicating new allelic combinations for all traits (Table 1). Significant phenotypic variation

162 existed among RILs for all quality parameters. Variation between environments was significant

163 for all traits except for FP (Table 2). Variance component analysis showed that genotypic variance

164 was higher than environmental variance for all traits except TW and AWRC. Heritability of the

165 ten quality traits ranged from 0.67 to 0.90 (Table 3 ).

166 The RILs means across environments were used for correlation analysis. Significant

167 positive correlations among RIL means for quality traits ranged from 0.17 to 0.88 , and significant

168 negative correlations ranged from -0.10 to -0.76 (Table 4 ). The WA, SO, SU and WARC were

169 highly positively correlated to one another and all were highly negatively correlated to FY.

\section{Linkage Map and QTL Analysis}

171 The 107 markers were assigned to 18 linkage groups (Fig. 5). The positions and order of

172 the markers were verified and in agreement with earlier published maps (Röder et al., 1998;

173 Gupta et al., 2002). Eight markers deviated significantly from the expected segregation ratio. The

174 dominant marker for HMW-glutenin subunit GluDx5 on chromosome 1D showed segregation 175 distortion.

176 Eight chromosome regions showed QTLs associated with one or more of the 10 quality

177 traits (Table 5). In total there were 28 significant trait-marker associations. One region of

178 chromosome $1 \mathrm{~A}$ affected six of 10 traits including traits for water absorption capacity (AWRC,

179 SO), gluten strength (LA, ADLA), and milling quality (FY, SE). This region had the greatest

180 effect of all regions for AWRC, LA, ADLA, and SO. One region of chromosome 1B affected 
181 five traits with a large effect on LA and ADLA $\left(\mathrm{r}^{2}=0.33-0.34\right)$. Regions of chromosomes $2 \mathrm{~B}, 3 \mathrm{~B}$,

$1824 \mathrm{~A}$, and $6 \mathrm{~B}$ all accounted for greater than $14.9 \%$ of the phenotypic variation for at least one trait.

183 For all 28 trait-marker associations the allele that increased the trait came from the parent

184 with the higher phenotypic value (Tables 1, 5). There were four QTL for water absorption traits

185 (AWRC, WA, SU, SO) on four chromosomes (1A, 1B, 4A, and 6B) (Table 5, Fig. 5). Three of

186 these four regions affected more than one water absorption capacity trait. In all 10 trait-marker

187 combinations for these traits the alleles from Pioneer 26R46 decreased the trait value and would

188 be the desired allele. QTL for milling traits (FY, SE) were detected on chromosomes 1A, 1B, 2B,

$1893 \mathrm{~B}, 4 \mathrm{~A}$, and 6B. For each the desired allele for SE came from SS550 while the desired alleles

190 from FY came from Pioneer 26R46. There were two regions (1A and 1B) associated the LA and

191 ADLA and neither were associated with FP. QTL for FP were detected on three regions (2B, 5A,

192 and 5D). Two regions were associated with TW on chromosomes 1B and 6B with the desired

193 allele coming from SS550. 


\section{DISCUSSION}

195 The mapping population derived from a cross of two elite SRWW lines offered the 196 opportunity to study the genetic determination and the identification of important areas of the

197 genome containing QTLs associated with specific components related to flour milling and

198 functional quality. In our study, the parents differed significantly for nine of 10 traits (Table 1)

199 and their phenotypes were in general correspondence to the values in 2005 report of the Soft

200 Wheat Quality Laboratory (SWQL) of The United States Department of Agricultural Research

201 Service (USDA, ARS) at Wooster, OH. The RILs showed a continuous phenotypic variation and

202 transgressive segregation. Heritability for all traits ranged from 0.67 to 0.90 (Table 3). Others

203 have reported similar heritability values for soft wheat quality traits (Baezinger et al., 1985;

204 Basset et al., 1989; Cabrera et al., 2015; Guttieri \& Souza, 2003; Hoffstetter et al., 2016; Smith et 205 al., 2011; Souza et al., 2002).

206 A total of 28 marker-trait associations were detected from eight chromosome regions

207 (Table 5). Some regions of the genome contained coincident QTLs associated with more than 208 one trait. The coincident QTL often corresponded to trait correlations (Table 4). The water 209 absorption capacity traits AWRC, WA, SU, and SO were all positively correlated as has been 210 reported by others for soft wheat (Guttieri \& Souza, 2003; Ram et al., 2005; Smith et al., 2011;

211 Cabrera et al., 2015; Hoffstetter et al., 2016). There were 10 marker-trait associations from four

212 regions for these traits and only one was not coincident with another. In all cases, the allele from

213 Pioneer 26R46 was the desired allele as it decreased water absorption, as would be predicted by

214 the parental phenotypes for these traits (Table 1). The results suggest that these markers along 215 with the parental phenotype could be used as good predictors of end-use functionality. FY was 216 negatively correlated with the water absorption capacity traits as has been reported by others

217 (Smith et al., 2011; Cabrera et al., 2015; Hoffstetter et al., 2016). Three of the four regions 218 associated with water absorption traits were also associated with FY. As expected from the 
219 correlations, if a QTL allele decreased water absorption it increased FY. This has been reported

220 by others is SRWW (Smith et al., 2011; Cabrera et al., 2015). Earlier studies explained that soft

221 wheat genotypes with less damaged starch and lower arabinoxylan content have higher flour

222 extraction (Guttieri et al., 2001). Finney and Bains (1999) explained that low FY cultivars that

223 perform very poorly during milling, have increased levels of damaged starch, and consequently

224 would have increased water absorption.

225 Loci associated with FP mapped on chromosomes 2B, 5B and 5D. QTLs on chromosome

226 2B co-segregated for SE: SE was negatively correlated (-0.26) with FP. A negative correlation of

$227-0.45$ between these traits was also observed in hard wheat (Gross et al., 2004) and others have

228 reported a negative correlation between these traits in soft wheat (Smith et al., 2011; Cabrera et

229 al., 2015; Hoffstetter et al., 2016). Genetic studies of kernel hardness in bread wheat indicated

230 that phenotypic expression of kernel hardness was tightly linked with FP (Galande et al., 2001),

231 but additional related traits such as arabinoxylan content also played an important role in kernel

232 hardness (Bettge \& Morris, 2000).

233 A positive significant correlation between FP and LA (0.36) was detected though the QTL

234 for these two traits were not coincident in this study. Positive correlations between these two

235 traits have been previously reported (Guttieri et al., 2001; Knott et al., 2009). However, in a study

236 of three soft wheat populations, just one population showed a positive correlation (0.47) between

237 these traits (Guttieri \& Souza, 2003). Lack of association of these two traits was also observed in

238 a study of soft white wheat (Guttieri et al., 2001). This association of LA and FP has been

239 explained by the effect of high molecular weight (HMW) glutenin subunits, which are part of the

240 total FP. A study of the influence of storage protein alleles on quality traits determined that HMW

241 glutenin alleles encoded at $G l u-A 1$ and $G l u-B 1$ cause significant differences in quality parameters

242 related to gluten strength (extensibility and strength), flour yield, and FP while HMW glutenin

243 subunits GluDx2 + GluDy12, GluDx3 + GluDy12, and GluDx4 + GluDy12, GluDx2 + GluDy12 
244 at the Glu-D1 locus, have no effect on extensibility, strength, flour yield, FP, and mixograph

245 parameters (Igrejas et al., 2002). In our study gluten strength functionality measured by LA was

246 independent to the other SRC tests, yet these traits have been reported to be positively associated

247 (Guttieri et al., 2001). The lack of correlation observed in our study was probably because LA is a

248 specific test for the glutenin network swelling behavior (Kweon et al., 2011). Major QTLs with

249 the largest effect on LA and consequently gluten strength were on chromosomes 1A with LOD 9

250 that explained $42.6 \%$ of LA variation and QTLs on chromosome 1B with LOD 9 that explained

$25133 \%$ of the variation in LA. Loci on chromosomes $1 \mathrm{~A}$ and $1 \mathrm{~B}$ were also important contributors of

252 additive effects with an increase of 6.5 and 5.6 percent, respectively. The two regions affecting

253 LA and ADLA on chromosomes $1 \mathrm{~A}$ and $1 \mathrm{~B}$ in our study are likely co-located with the Glu-A1 254 and Glu-B1 loci.

255 QTL on chromosome 2B were previously found in bread wheat recombinant substitution 256 lines and in a soft $\mathrm{x}$ hard wheat population (Campbell et al., 2001; Turner et al., 2004). Cabrera 257 et al. (2015) and Smith et al. (2011) reported that 2B was one of the key chromosomes 258 controlling soft wheat quality, along with 1B. Pioneer 26R46 carries the 1BL:1RS translocation 259 that has been shown to have a large effect on soft wheat quality (McKendry et al., 1996; 260 McKendry et al., 2001; Cabrera et al., 2015). The IBL:1RS is often detrimental to quality though

261 Pioneer 26R46 shows superior quality anyways. The effect of $2 \mathrm{~B}$ on quality traits can be partly 262 attributed in some crosses to the T. timopheevi translocation associated with Sr36 (Allard \& 263 Shands, 1954; Tsilo et al., 2008) and to allelic variation for sucrose synthase (Cabrera et al., 264 2015). 


\section{CONCLUSIONS}

This study validates some previous findings in soft wheat that chromosomes $1 \mathrm{~B}$ and $2 \mathrm{~B}$ are important to soft wheat quality. Previous studies have not shown the regions of $1 \mathrm{~A}$ to be as important for soft wheat quality as we are reporting here. Perhaps some novel alleles from Pioneer 26R46 are causing the large effects associated with 1A and contributing to the very high quality of grain from Pioneer 26R46. particular marker allele: MAS is executed in a lineage derived from the donor, thus assuring that identity-by-state at the marker reflects identity by descent at the QTL. In this study the parents with the favorable phenotype always contributed the favorable alleles at key QTL, similar to the results from Cabrera et al. (2015). This suggests that in other crosses that one could select for superior progeny by selecting for the best parent's marker alleles at the key loci (say 1A, 1B, 2B, $6 \mathrm{~B})$, even without prior determination of the effects of these marker alleles from these parents. Our findings support the similar conclusion made by Cabrera et al. (2015). Thus instead of using marker-assisted selection to bred for a QTL derived from a single ancestor, one could possibly use MAS in any cross by selecting for markers from the superior parent, regardless of their ancestral source. 
282

283

284

285

286

287

288

289

290

291

292

293

294

295

296

297

298

299

300

301

302

303

304

305

306

307

308

309

310

311

312

313

314

315

316

317

318

\section{REFERENCES}

Allard RW \& Shands RG. 1954. Inheritance of resistance to stem rust and powdery mildew in cytologically stable spring wheats derived from Triticum timopheevi. Phytopathology 44: 266274.

American Association of Cereal Chemists AACC. 1983. Approved methods. 8 ed. St. Paul(MN)

Baenziger PS, Clements RL, McIntosh MS, Yamazaki WT, Starling TM, Sammons DJ, Johnson JW. 1985. Effect of cultivar, environment, and their interaction and stability analyses on milling and baking quality of soft red winter wheat. Crop Science 25: 5-8.

Basset LM, Allan RE, Rubenthaller GL. 1989. Genotype x environment interactions on soft white winter quality. Agronomy Journal 81: 955-960.

Bettge AD, Morris CF. 2000. Relationship among grain hardness, pentosan fractions and end use quality of wheat. Cereal Chemestry 77: 241-247.

Blanco A, De Giovanni C, Laddomada B, Sciancalerope A, Simeone R, Devos KM, Gale MD. 1996. Quantitative trait influencing grain protein content in tetraploid wheat. Plant Breeding 115: 310-316

Cabrera A, Guttieri M, Smith N, Souza E, Sturbaum A, Hua D, Griffey C, Barnett M, Murphy P, Ohm H, Uphaus J, Sorrells ME, Heffner E, Brown-Guedira G, Van Sanford D, Sneller CH. 2015, Identification of milling and baking quality QTLs in multiple soft wheat mapping populations. Theoretical Applied Genetics 128:2227-2242. DOI 10.1007/s00122-015-2580-3

Campbel K, Finney P, Bergman C, Gualberto D, Anderson J, Giroux M, Siritunga D, Zhu J, Gendre F, Roue C, Vèrel A, Sorrels M. 2001. Quantitative trait loci associated with milling and baking quality in a soft $\mathrm{x}$ hard wheat cross. Crop Science 41:1275-1285.

Cregan PB, Ward R, Gill BS. 2001. Preliminary BARC SSR maps and primer pair details. [Online] Available at: http://www.scabusa.org/research_bio.html [Accessed August 2005].

D' Ovidio R, Anderson OD. 1994. PCR analysis to distinguish between alleles of a member of a multigene family correlated with bread-making quality. Theoretical Applied Genetics 88:759763.

Finney P, Andrews LC. 1986. Revised microtesting for soft wheat quality evaluation. Cereal Chem. 63: 177-182.

Finney PL, Bains GS. 1999. Protein functionality differences in Eastern U.S. soft wheat cultivars and interrelation with end-use quality tests. Lebensm.-Wiss. u. Technology 32:406- 415.

Gaines CS. 2000. Report of the AACC committee of soft wheat flour. Method 56-11. Solvent retention capacity profile. Cereal Foods World 45: 303-306.

Galande AA, Tiwari R, Ammiraju JSS, Santra .K, Lagu MD, Rao VS, Gupta VS, Misra BK, Nagarajan S, Ranjekar PK. 2001. Genetic analysis of kernel hardness in bread wheat using PCRbased markers. Theoretical Applied Genetics 103: 601-606. 
319 Gale K, Ma W, Zhang W, Johal J, Butow BJ. 2003. Simple DNA markers for genes influencing 320 wheat quality. P. 435-438. In N. E. Pogna, M. Romano, E. Pogna, G. Galterio (ed.) Tenth 321 international Wheat genetics symposium. Paestum, Italy.

322 Graybosch RA, Peterson CJ, Shelton DR, Baenziger PS. 1996. Genotypic and environmental 323 modification of wheat flour protein composition in relation to end-use quality. Crop Sciece 36: $324 \quad 296-300$

325 Gross C, Bervas E, Charmet G. 2004. Genetic analysis of grain protein content, grain hardness 326 and dough rheology in a hard $\mathrm{x}$ hard bread wheat progeny. Journal of Cereal Science 40:93:100.

327 Gupta PK, Balyan HS, Edwards KJ, Issac P, Korzum V, Röder M, Gautier NF, Joudrier P, 328 Schlatter A, Dukobsky J, De la Pena RC, Khairallah M, Penner G, Hayden MJ, Sharp P, Keller B, 329 Wang RCC, Hardouin JP, Jack P, Leroy P. 2002. Genetic mapping of 66 new satellite (SSR) loci 330 in bread wheat. Theoretical Applied Genetics 105: 413-422.

331 Gupta RB, Singh NK, Shepherd KW. 1989. The cumulative effect of allelic variation in LMW 332 and HMW glutenin subunits on dough properties in the progeny of two bread wheats. Theoretical 333 Applied Genetics 77: 57-64.

334 Guttieri M, Bowen D, Gannon D, O’Brien K, Souza E. 2001. Solvent retention capacities of 335 irrigated soft white spring wheat flours. Crop Science 41:1054-1061.

336 Guttieri M, Souza E. 2003. Sources of variation in the solvent retention capacity test of wheat 337 flour. Crop Science 43:1628-1633

338 Hamer RJ, Weegels PL, Marseille P. 1992. Prediction of the breadmaking quality of wheat:the 339 use of HMW glutenin-A subunit-based quality scoring systems. Journal of Cereal Science 340 15:91-102. doi.org/10.1016/S0733-5210(09)80059-3

341 Harberdt NP, Bartels D, Thompsom RD. 1986. DNA restriction-fragment variation in the gene 342 family encoding high-molecular-weight (HMW) glutenin subunits of wheat. Biochem. Genet. 343 24:579-595.

344 Hoffstetter AL, Cabrera A, Sneller CH. 2016. Identifying quantitative trait loci for economic 345 traits in an elite soft red winter wheat population. Crop Science 56:1-12.

346 doi: 10.2135/cropsci2015.06.0332

347 Igrejas G, Huedes-Pinto H, Carnide V, Clement J, Branlard G. 2002. Genetic, biochemical, and 348 technological parameters associated with biscuit quality. II. Prediction using storage proteins and 349 quality characteristics in a soft wheat population. Journal of Cereal Science 36:187-197.

350 Knott C, Van Sanford D, Souza E. 2009. Genetic Variation and the Effectiveness of Early351 Generation Selection for Soft Winter Wheat Quality and Gluten Strength. Crop Science 49:113352117 doi:10.2135/cropsci2008.05.0290

353 Kweon M, Slade L, Levine H. 2011. Solvent Retention Capacity (SRC) Testing of Wheat Flour: 354 Principles and Value in Predicting Flour Functionality in Different. Wheat-Based Food Processes 
355 and in Wheat Breeding-A Review. Cereal Chemestry 88 (6): 537- 552. doi:10.1094/CCHEM$356 \quad 07-11-0092$

357 Manley M, Randall PG, McGill AEJ. 1992. The prediction of dough properties of South African 358 wheat cultivars by SDS-PAGE Analysis of HMW glutenin subunits. Journal of Cereal Science 359 15:39-47 doi.org/10.1016/S0733-5210(09)80055-6

360 Mansur L, Qualset C, Kasarda D, Morris R. 1990. Effects of 'Cheyene' chromosomes on milling 361 and baking quality in 'chinese spring' wheat in relation with glutenin and gliadin storage proteins. 362 Crop Science 30: 593-602.

363 Marshall D R, Mares DJ, Moss HJ, Ellison FW. 1986. Effects of grain shape and size on milling 364 yields in wheat. II. Experimental studies. Australian Journal of Agriculture Research 37:331-342.

365 Mattern PJ, Morris R, Schmidt JW, Johnson VA. 1973. Locations of genes for kernel properties in 366 the wheat variety "Cheyenne" using chromosome substitution lines. In Proc. 4th Int Wheat Genet 367 Symp. Columbus, Missouri, pp 703-707.

368 McKendry AL, Tague DN, Finney PL, Miskin KE. 1996. Effect of 1BL.1RS on Milling and 369 Baking Quality of Soft Red Winter Wheat. Crop Science 36:848-851

370 McKendry AL, Tague DN, Ross K. 2001. Comparative Effects of 1BL.1RS and 1AL.1RS on 371 Soft Red Winter Wheat Milling and Baking Quality Research funded in part by the Biscuit and 372 Cracker Manufacturers Association of America. Crop Science 41:712-720

373 Nieto-Taladriz MT, Perretant MR, Rousset M. 1994. Effect of gliadins, and HMW and LMW 374 subunits of glutenin on dough properties in the F6 recombinant inbred lines from a bread wheat 375 cross. Theoretical Applied Genetics 88: 81-88

376 Payne PI, Holt LM, Law CN. 1981. Structural and genetical studies on the high molecular 377 subunits amongst varieties of wheat (T. aestivum). Theoretical Applied Genetics 60: 229-236.

378 Perretant MR, Cadalen T, Charmet G, Sourdille P, Nicolas P, Boeuf C, Tixier MH, Branlard G, 379 Bernard S, Bernard M. 2000. Qtl analysis of bread-making quality in wheat using a doubled 380 haploid population. Theoretical Applied Genetics 100: 1167-1175.

381 Prasad M, Varshney RK, Kumar A, Balyan HS, Sharma PC, Edwards KJ, Singh H, Dhaliwal HS, 382 Roy JK, Gupta PK. 1999. A microsatellite marker associated with a QTL for grain protein content 383 on chromosome arm 2DL of bread wheat. Theoretical Applied Genetics 99:341-345.

384 Prasad M, Kumar A, Kulwal PL, Roder MS, Balyan HS, Dhaliwal HS, Gupta PK. 2003. Qtl 385 analysis for grain protein content using SSR markers and validation studies using NILs in bread 386 wheat. Theoretical Applied Genetics 106: 659-667.

387 Ram S, Dawar V, Singh R P, and Shoran J. 2005. Application of solvent retention capacity tests 388 for the prediction of mixing properties of wheat flour. Theoretical Applied Genetics 42:261-266.

389 Röder M, Korzum V, Wendehake K, Plaschke J, Tixier MH, Leroy P, Ganal M. 1998. A 390 microsatellite map of wheat. Genetics.149: 2007-2023. 
391 Rpusset MJ, Carrillo M, Qualset CO \& Kasarda DD. 1992. Use of recombinant inbred lines for 392 study of associations of high molecular weight glutenin subunit alleles to quantitative traits. 393 Theoretical Applied Genetics 83: 403-412.

394 SAS Institute. 1994. SAS User's Guide: Statistics. SAS Institute, Cary, NC.

395 Slade L, Levine H. 1994. Structure-function relationships of cookie and cracker ingredients. p. 396 23-141. In H. Farid (ed.). The science of cookie and cracker production. Chapman and Hall/AVI, 397 New York, N.Y.

398 Smith N, Guttieri M, Souza E, Shoots J, Sorrells M, Sneller C. 2011. Identification and

399 Validation of QTL for Grain Quality Traits in a Cross of Soft Wheat Cultivars Pioneer Brand

400 25R26 and Foster. Crop Science 51:1424-1436. doi: 10.2135/cropsci2010.04.0193

401 Sourdille M, Perrant R, Charmet G, Leroy P, Gautier MF, Nelson JC, Sorrels ME, Bernard M. 402 1996. Linkage between RFLP markers and genes affecting kernel hardness in wheat. Theoretical 403 Applied Genetics 93: 580-586.

404 Souza E, Graybosch R A, Guttieri M J. 2002. Breeding wheat for improved milling and baking 405 quality. P. 39-74. In A.S. Basra and L.S. Randhawa (ed.) Quality improvement in field crops. The 406 Haworth Press, Inc.

407 Tsilo TJ, Jin Y, and Anderson JA. 2008. Diagnostic microsatellite markers for the detection of 408 stem rust resistance gene Sr36 in diverse genetic backgrounds of wheat. Crop Science 48(1):253409261

410 Turner AS, Bradburner RP, Fish L, Sanpe JW. 2004. New quantitative trait loci influencing grain 411 texture and protein content in bread. Journal of Cereal Science 40:51-60.

412 VaOoijen JW, Voorrips RE. 2001. JoinMap 3.0 software for the calculation of genetic linkage 413 maps. Plant Research International. Wageningen, The Netherlands.

414 Van Ooijen W. 2002. MapQTL 4.0 Sotware for the calculation of QTL position on genetic maps. 415 Plant Research International. Wageningen, The Netherlands. 


\section{Table $\mathbf{1}$ (on next page)}

Parental and population means, and maximum and minimum values for each quality trait of 150 soft red winter wheat RIL combined over four environments 
Table 1. Parental and population means, and maximum and minimum values for each quality trait of 150 soft red winter wheat RIL combined over four environments

\begin{tabular}{|c|c|c|c|c|c|}
\hline Trait & $\begin{array}{l}\text { RIL } \\
\text { mean }\end{array}$ & $\begin{array}{c}\text { Pionee } \\
\text { r } \\
\text { 26R46 }\end{array}$ & $\begin{array}{c}\text { SS55 } \\
0\end{array}$ & $\begin{array}{c}\text { RIL } \\
\text { maximum }\end{array}$ & $\begin{array}{c}\text { RIL } \\
\text { minimu } \\
\mathrm{m}\end{array}$ \\
\hline $\mathrm{TW} \dagger\left(\mathrm{kg} \mathrm{m}^{-3}\right)$ & 778 & $767^{*}$ & 789 & 833 & 733 \\
\hline AWRC (\%) & 534 & $52 *$ & 57 & 61 & 49 \\
\hline $\mathrm{FP}\left(\mathrm{g} \mathrm{kg}^{-1}\right)$ & 103 & $99^{\mathrm{ns}}$ & 102 & 120 & 83 \\
\hline $\mathrm{LA}\left(\mathrm{g} \mathrm{kg}^{-1}\right)$ & 949 & $1003^{*}$ & 922 & 1346 & 650 \\
\hline $\operatorname{ADLA}\left(\mathrm{g} \mathrm{kg}^{-1}\right)$ & 860 & $943^{*}$ & 838 & 1250 & 567 \\
\hline $\mathrm{WA}\left(\mathrm{g} \mathrm{kg}^{-1}\right)$ & 514 & $491 *$ & 539 & 559 & 475 \\
\hline $\mathrm{SU}\left(\mathrm{g} \mathrm{kg}^{-1}\right)$ & 833 & $815^{*}$ & 895 & 963 & 752 \\
\hline $\mathrm{SO}\left(\mathrm{g} \mathrm{kg}^{-1}\right)$ & 626 & $597 *$ & 674 & 717 & 562 \\
\hline FY (\%) & 72 & $72 *$ & 68 & 74 & 63 \\
\hline SE $(\%)$ & 53 & $55^{*}$ & 56 & 61 & 39 \\
\hline \multicolumn{6}{|c|}{$\begin{array}{l}\text { * indicates a significant difference between parental means at the } P<0.05 \text { level } \\
\text { not significant } \\
\dagger \mathrm{TW}=\text { test weight, } \mathrm{AWRC}=\text { alkaline water retention capacity, } \mathrm{FP}=\text { flour protein, } \\
\mathrm{LA}=\text { lactic acid } \mathrm{SRC}, \mathrm{ADLA}=\text { adjusted } \mathrm{LA}, \mathrm{WA}=\text { water } \mathrm{SRC}, \mathrm{SU}=\text { sucrose } \mathrm{SRC} \text {, } \\
\mathrm{SO}=\text { sodium carbonate } \mathrm{SRC}, \mathrm{FY}=\text { flour yield, } \mathrm{SE}=\text { softness equivalent }\end{array}$} \\
\hline
\end{tabular}




\section{Table 2 (on next page)}

Sum of squares of the combined ANOVA for ten quality parameters of 150 soft red winter wheat RIL from four environments 
Table 2. Sum of squares of the combined ANOVA for ten quality parameters of 150 soft red winter wheat RIL from four environments

\begin{tabular}{|c|c|c|c|}
\hline \multirow{2}{*}{ Solvent retention capacities } & \multicolumn{2}{|c|}{ Source of variation } & \multirow{2}{*}{$*$ and $* *$ indicate } \\
\hline & Environment & RIL & \\
\hline $\mathrm{TW} \dagger\left(\mathrm{kg} \mathrm{m}^{-3}\right)$ & $630 * *$ & $4.9^{* *}$ & significance at $P$ \\
\hline AWRC (\%) & $468^{* *}$ & $6.8 * *$ & $<0.05$ and $P<$ \\
\hline $\mathrm{FP}\left(\mathrm{g} \mathrm{kg}^{-1}\right)$ & $3^{\mathrm{ns}}$ & $5.8^{* *}$ & 0.001, \\
\hline $\mathrm{LA}\left(\mathrm{g} \mathrm{kg}^{-1}\right)$ & $46^{* *}$ & $15.2^{*}$ & $\begin{array}{l}\text { respectively; } \\
\text { not significant. }\end{array}$ \\
\hline $\operatorname{ADLA}\left(\mathrm{g} \mathrm{kg}^{-1}\right)$ & $60 * *$ & $15.4^{* *}$ & $\uparrow \mathrm{TW}=$ test \\
\hline $\mathrm{WA}\left(\mathrm{g} \mathrm{kg}^{-1}\right)$ & $24 * *$ & $8.8^{* *}$ & weight, \\
\hline $\mathrm{SU}\left(\mathrm{g} \mathrm{kg}^{-1}\right)$ & $162 * *$ & $6.5 * *$ & AWRC $=$ alkaline \\
\hline $\mathrm{SO}\left(\mathrm{g} \mathrm{kg}^{-1}\right)$ & $73^{* *}$ & $9.1 * *$ & water retention \\
\hline FY $(\%)$ & $180 * *$ & $6.4^{* *}$ & capacity, \\
\hline SE $(\%)$ & $394 * *$ & $8.5^{* *}$ & $\mathrm{FP}=$ flour protein, \\
\hline
\end{tabular}

$\mathrm{SRC}, \mathrm{ADLA}=$ adjusted LA, $\mathrm{WA}=$ water $\mathrm{SRC}, \mathrm{SU}=$ sucrose $\mathrm{SRC}, \mathrm{SO}=$ sodium carbonate $\mathrm{SRC}, \mathrm{FY}=$ flour yield, $\mathrm{SE}=$ softness equivalent 


\section{Table 3(on next page)}

Heritability and variance components across environments

Heritability and variance components across environments for ten quality parameter in soft red winter wheat 
Table 3. Heritability and variance components across environments for ten quality parameter in soft red winter wheat

\begin{tabular}{llllll}
\hline \multirow{2}{*}{$\begin{array}{l}\text { Solvent retention } \\
\text { capacities }\end{array}$} & $\sigma^{2}$ env & $\sigma^{2} \mathrm{~g}$ & $\sigma^{2}$ error & $\sigma^{2} \mathrm{~g} / \sigma_{\text {error }}^{2}$ & $\mathrm{~h}^{2}$ \\
\hline $\mathrm{TW} \dagger\left(\mathrm{kg} \mathrm{m}^{-3}\right)$ & 1.90 & 0.46 & 0.40 & 1.10 & 0.81 \\
$\mathrm{AWRC}(\%)$ & 2.40 & 1.00 & 2.10 & 2.80 & 0.67 \\
$\mathrm{FP}\left(\mathrm{g} \mathrm{kg}^{-1}\right)$ & 0.0001 & 0.20 & 0.20 & 1.00 & 0.80 \\
$\mathrm{LA}\left(\mathrm{g} \mathrm{kg}^{-1}\right)$ & 162 & 830 & 341 & 0.50 & 0.91 \\
$\mathrm{ADLA}\left(\mathrm{g} \mathrm{kg}^{-1}\right)$ & 157 & 842 & 298 & 2.40 & 0.92 \\
$\mathrm{WA}\left(\mathrm{g} \mathrm{kg}^{-1}\right)$ & 0.05 & 1.20 & 0.80 & 1.50 & 0.90 \\
$\mathrm{SU}\left(\mathrm{g} \mathrm{kg}^{-1}\right)$ & 2.50 & 6.70 & 4.80 & 1.40 & 0.85 \\
$\mathrm{SO}\left(\mathrm{g} \mathrm{kg}^{-1}\right)$ & 1.70 & 4.20 & 2.30 & 1.90 & 0.90 \\
$\mathrm{FY}(\%)$ & 0.30 & 1.10 & 0.90 & 1.30 & 0.84 \\
$\mathrm{SE}(\%)$ & 2.70 & 4.90 & 2.20 & 2.20 & 0.90 \\
\hline$\dagger \quad \mathrm{TW}=$ test weight, & AWRC=alkaline water retention capacity, FP=flour protein, LA=lactic acid SRC, \\
ADLA=adjusted LA, WA=water SRC, SU= sucrose SRC, SO=sodium carbonate SRC, FY=flour yield, SE=softness \\
equivalent
\end{tabular}




\section{Table 4(on next page)}

Pearson's correlation coefficients for ten quality parameters

Pearson's correlation coefficients for ten quality parameters of 150 soft red winter wheat RIL 
Table 4. Pearson's correlation coefficients for ten quality parameters of 150 soft red winter wheat RIL

\begin{tabular}{|c|c|c|c|c|c|c|c|c|c|}
\hline & $\mathrm{FP \dagger}$ & LA & ADLA & AWRC & WA & $\mathrm{SU}$ & $\mathrm{SO}$ & FY & $\mathrm{SE}$ \\
\hline TW & $0.17 *$ & $0.18^{*}$ & ns & ns & $0.24 * * *$ & ns & $0.20 *$ & ns & ns \\
\hline FP & & $0.36^{* *}$ & ns & ns & $0.23 * *$ & ns & ns & ns & $-0.26 * * *$ \\
\hline LA & & & $0.95 * * *$ & $-0.22 * *$ & ns & ns & ns & ns & $0.05 * *$ \\
\hline ADLA & & & & $-0.10 * *$ & ns & $0.33 * *$ & ns & ns & ns \\
\hline AWRC & & & & & $0.71 * * *$ & $0.66 * * *$ & $0.88 * * *$ & $-0.64 * * *$ & $0.43 * * *$ \\
\hline WA & & & & & & $0.80 * * *$ & $0.79 * * *$ & $-0.63 * * *$ & $\mathrm{~ns}$ \\
\hline SU & & & & & & & $0.79 * * *$ & $-0.75 * * *$ & ns \\
\hline $\mathrm{SO}$ & & & & & & & & $-0.76 * * *$ & $0.50 * * *$ \\
\hline FY & & & & & & & & & $-0.50 * * *$ \\
\hline
\end{tabular}

$* P<0.05, * * \mathrm{P}<0.01, * * * \mathrm{P}<0.001 .{ }^{\mathrm{ns}}$, not significant.

$\uparrow \mathrm{TW}=$ test weight, $\mathrm{AWRC}=$ alkaline water retention capacity, $\mathrm{FP}=$ flour protein, $\mathrm{LA}=$ lactic acid $\mathrm{SRC}$,

$\mathrm{ADLA}=$ adjusted LA, WA=water $\mathrm{SRC}, \mathrm{SU}=$ sucrose $\mathrm{SRC}, \mathrm{SO}=$ sodium carbonate $\mathrm{SRC}, \mathrm{FY}=$ flour yield, $\mathrm{SE}=$ softness equivalent 


\section{Table 5 (on next page)}

Chromosomes with QTLs controlling quality traits detected by composite interval mapping in soft red winter wheat 
Table 5. Chromosomes with QTLs controlling quality traits detected by composite interval mapping in soft red winter wheat

\begin{tabular}{|c|c|c|c|c|c|}
\hline Chromosome & Interval & Trait $^{\dagger}$ & $\begin{array}{l}\% \\
\text { variation }\end{array}$ & LOD & $\begin{array}{l}\text { Additive } \\
\text { effect of } \\
\text { Pioneer } \\
\text { 26R46 }\end{array}$ \\
\hline \multirow[t]{6}{*}{$1 \mathrm{AL}$} & Barc120-Barc148 & LA & 42.6 & 9.0 & 6.5 \\
\hline & Barc120-Barc148 & ADLA & 36.0 & 8.0 & 6.0 \\
\hline & Barc120-Barc148 & AWRC & 25.0 & 6.0 & -0.6 \\
\hline & Barc120-Barc148 & SO & 26.0 & 6.0 & -1.3 \\
\hline & Barc120-Barc148 & SE & 25.0 & 5.0 & -1.2 \\
\hline & Barc120-Barc148 & FY & 15.0 & 3.0 & 0.4 \\
\hline \multirow{5}{*}{$1 \mathrm{BL}$} & Barc181-Barc137 & TW & 17.0 & 5.0 & -0.5 \\
\hline & Xgwm273-Barc137 & LA & 33.0 & 9.0 & 5.6 \\
\hline & Xgwm273-Barc137 & ADLA & 34.0 & 9.0 & 5.2 \\
\hline & Xgwm273-Barc137 & $\mathrm{SO}$ & 11.0 & 2.8 & -0.6 \\
\hline & Barc181-Barc137 & SE & 12.0 & 3.4 & -0.7 \\
\hline \multirow[t]{2}{*}{$2 \mathrm{~B}$} & Xgwm630-Wmc149 & FP & 16.0 & 5.0 & -0.2 \\
\hline & Xgwm630-Wmc149 & SE & 7.5 & 2.3 & 0.6 \\
\hline \multirow[t]{2}{*}{$3 \mathrm{~B}$} & Barc147-Cfd79 & SE & 20.0 & 5.0 & -1.0 \\
\hline & Wmc78-Wmc231 & FY & 10.0 & 3.2 & 0.4 \\
\hline \multirow[t]{5}{*}{$4 \mathrm{~A}$} & Xgwm111-Barc184 & AWRC & 10.0 & 2.9 & -0.4 \\
\hline & Xgwm111-Barc184 & SU & 12.0 & 3.7 & -0.9 \\
\hline & Xgwm111-Barc184 & SO & 15.0 & 4.6 & -0.8 \\
\hline & Xgwm111-Barc184 & SE & 8.4 & 2.8 & -0.7 \\
\hline & Xgwm111-Barc184 & FY & 13.5 & 4.2 & 0.4 \\
\hline $5 \mathrm{~A}$ & Barc141-Barc151 & FP & 10.0 & 2.9 & -0.17 \\
\hline $5 \mathrm{D}$ & Barc286-Xgwm182 & FP & 12.7 & 2.5 & -0.2 \\
\hline \multirow[t]{6}{*}{$6 \mathrm{~B}$} & Barc198-Wms816 & TW & 12.5 & 3.8 & -0.3 \\
\hline & Barc198-Wms816 & AWRC & 12.0 & 4.0 & -0.5 \\
\hline & Barc198-Wms816 & WA & 22.0 & 7.8 & -0.6 \\
\hline & Barc198-Wms816 & SU & 31.0 & 7.8 & -1.6 \\
\hline & Barc198-Wms816 & $\mathrm{SO}$ & 18.0 & 6.0 & -0.9 \\
\hline & Barc198-Wms816 & FY & 10.0 & 3.0 & 0.4 \\
\hline
\end{tabular}

$\dagger \mathrm{TW}=$ test weight, $\mathrm{AWRC}=$ alkaline water retention capacity, $\mathrm{FP}=$ flour protein, $\mathrm{LA}=$ lactic acid $\mathrm{SRC}$, ADLA=adjusted $\mathrm{LA}, \mathrm{WA}=$ water $\mathrm{SRC}, \mathrm{SU}=$ sucrose $\mathrm{SRC}, \mathrm{SO}=$ sodium carbonate $\mathrm{SRC}, \mathrm{FY}=$ flour yield, $\mathrm{SE}=$ softness equivalent 


\section{Figure 1 (on next page)}

Distribution of average flour protein values for wheat recombinant inbred lines and their parents. 


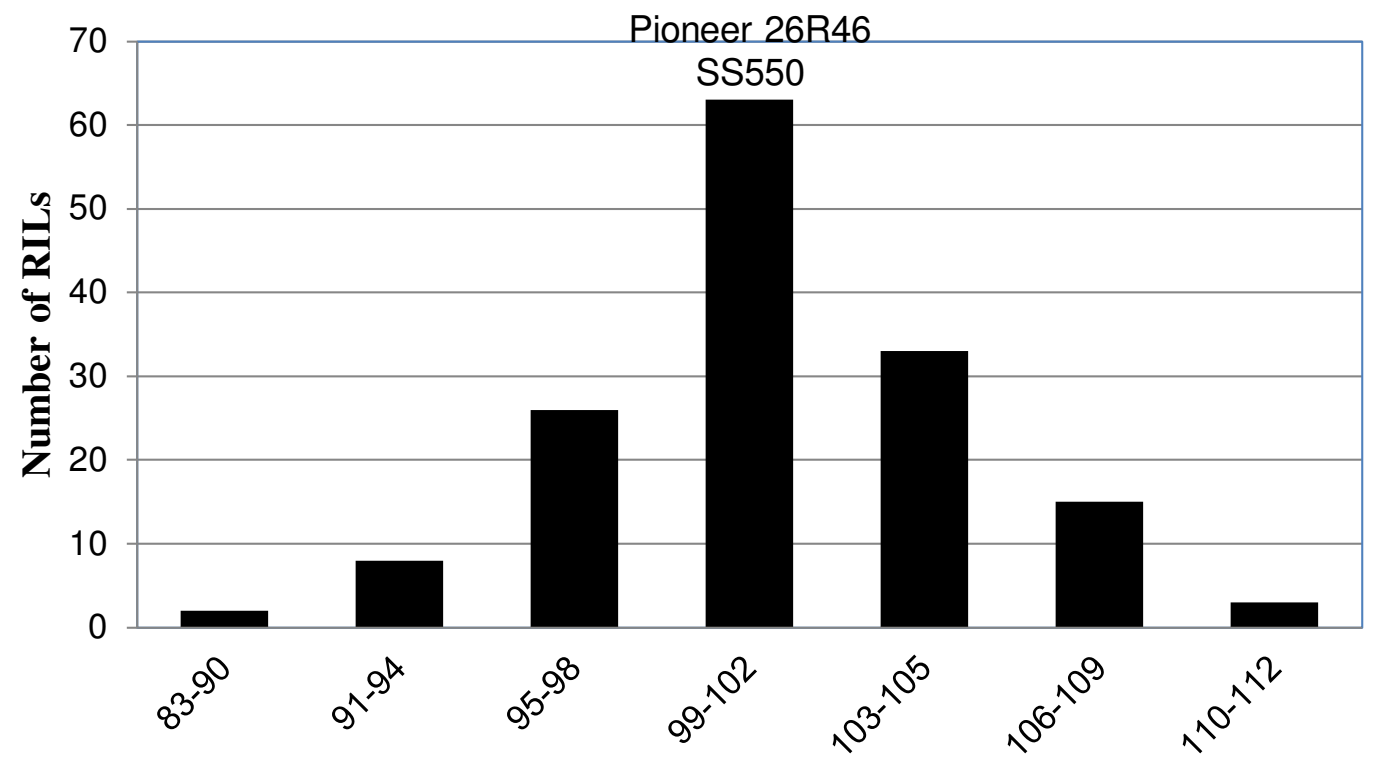

Range of Flour Protein $\left(\mathrm{g} \mathrm{kg}^{-1}\right)$ 


\section{Figure 2 (on next page)}

Distribution of average lactic acid SRC values for wheat recombinant inbred lines and their parents 


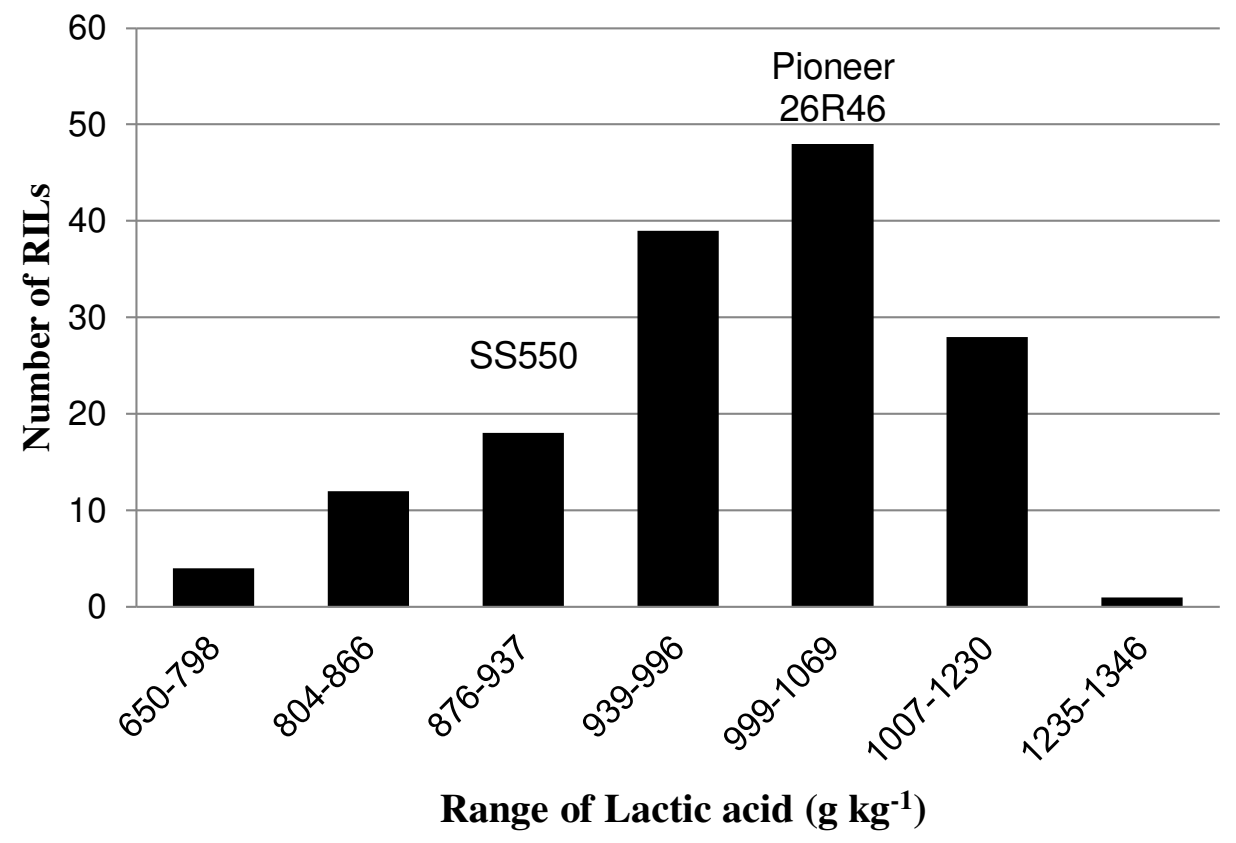




\section{Figure 3 (on next page)}

Distribution of average flour yield values for wheat recombinant inbred lines and their parents. 


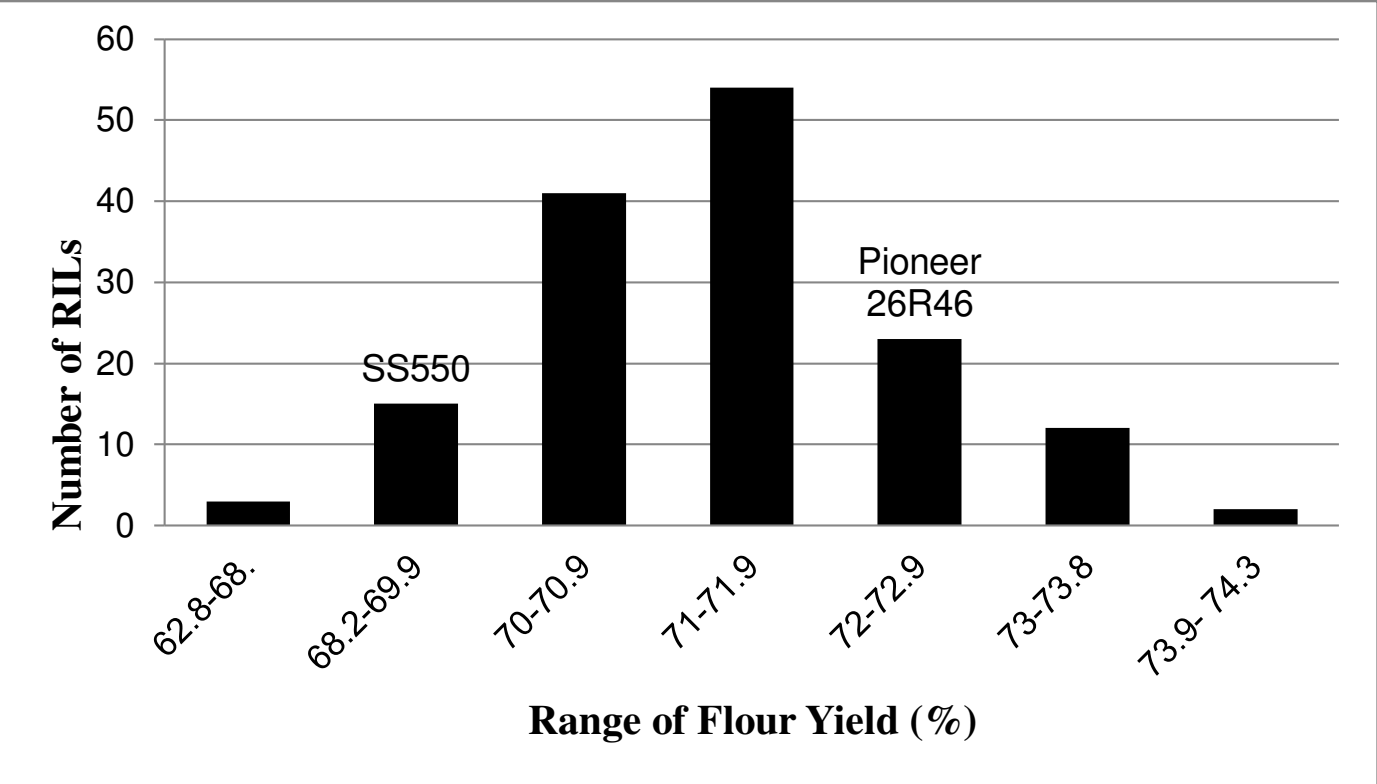


Figure 4(on next page)

Distribution of average softness equivalent values for wheat recombinant inbred lines and their parents 


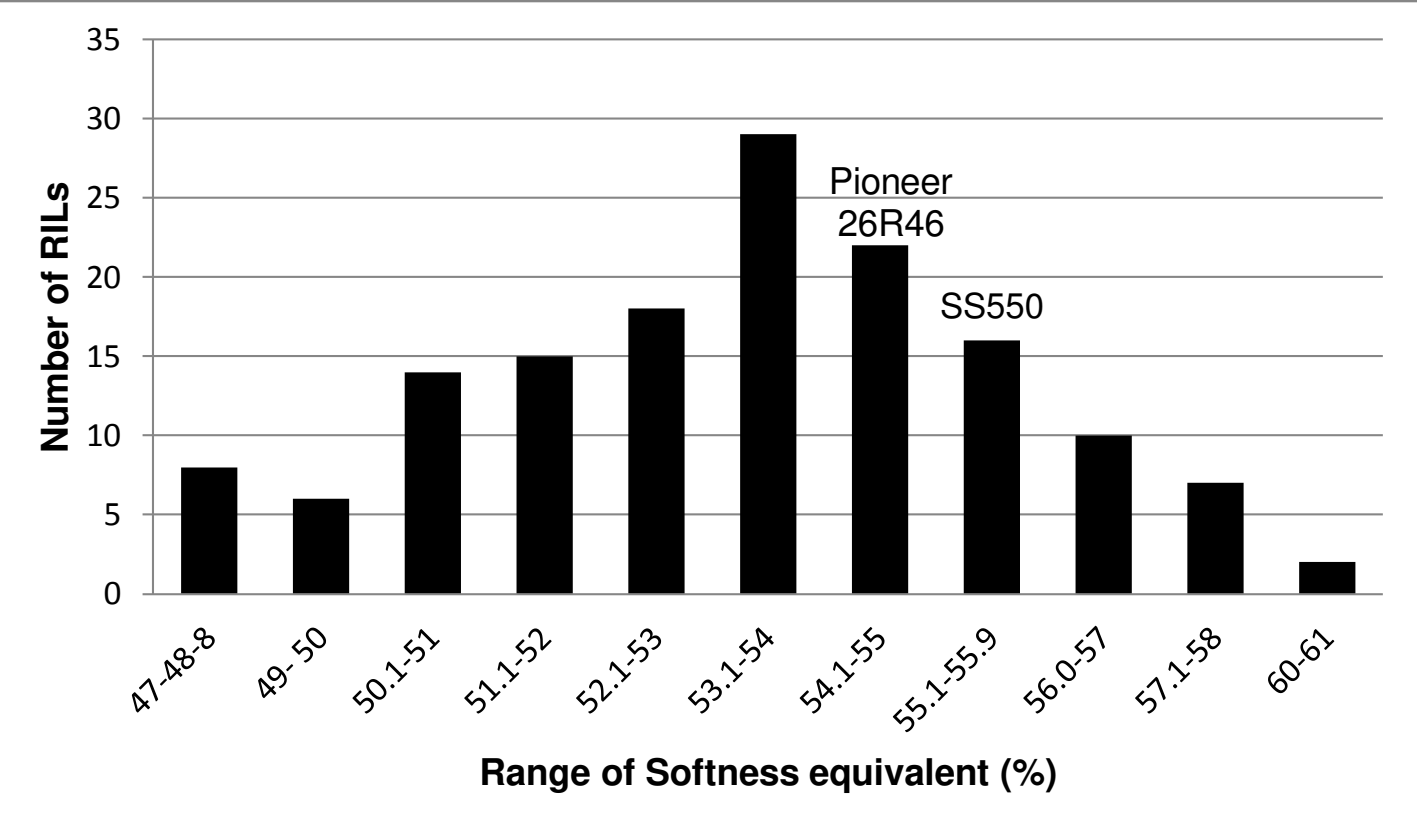


Figure $\mathbf{5}$ (on next page)

Genomic locations of QTLs for ten quality traits in a mapping population of 150 soft red winter wheat recombinant inbred lines.

Map distances (CM) are show on the left and marker names are show on the right. Marker positions were deduced by comparison with other maps. Segregation distortion is indicated with (sk). TW=test weight, $A W R C=a l k a l i n e$ water retention capacity, $F P=$ flour protein, $L A=$ lactic acid $S R C, A D L A=$ adjusted $L A, W A=$ water $S R C, S U=$ sucrose $S R C, S O=$ sodium carbonate $\mathrm{SRC}, \mathrm{FY}=$ flour yield, $\mathrm{SE}=$ softness equivalent 


\section{PeerJ}

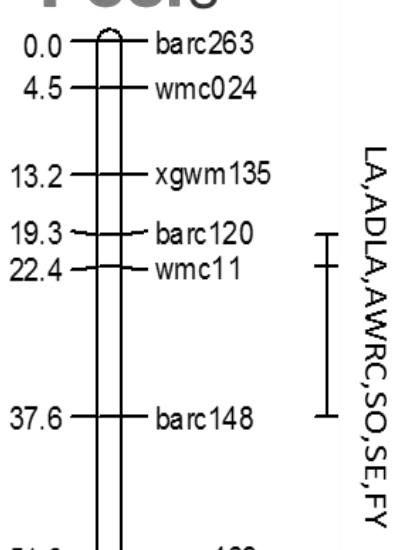

$2 A$

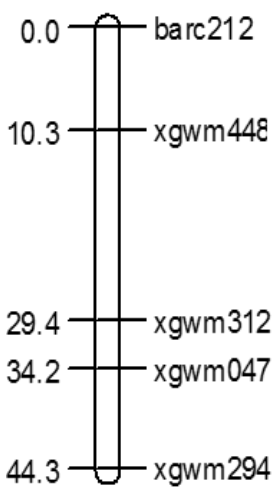

58.3 -

$64.3-$ barc017sk

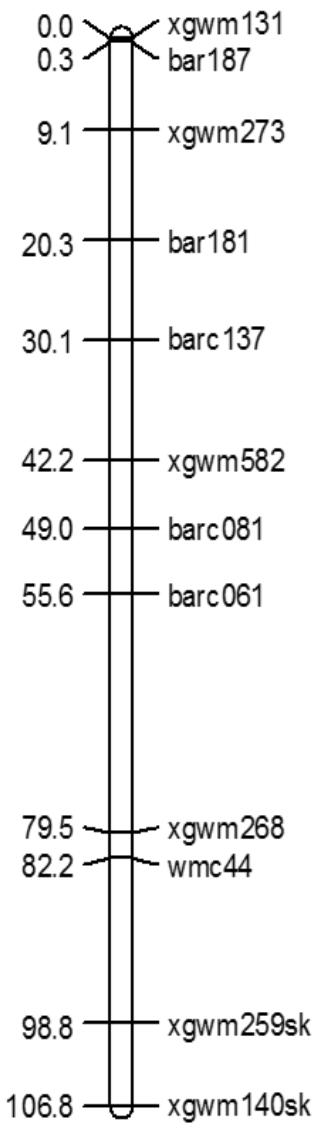

Manuscript to be reviewed

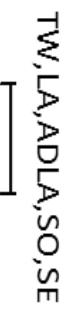

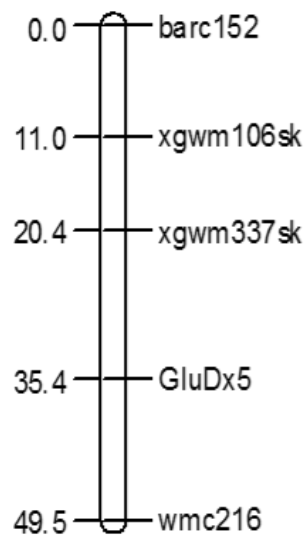

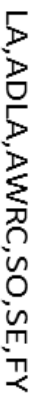

2B

2D

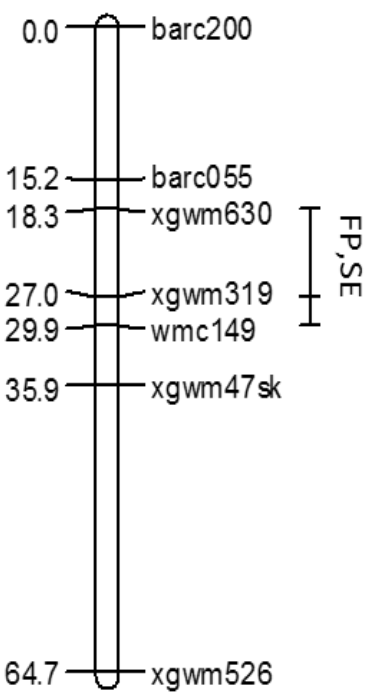

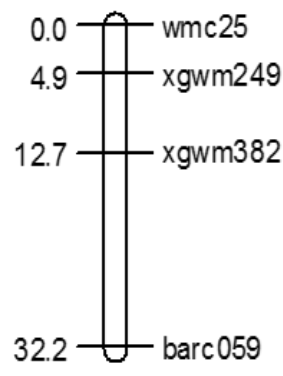




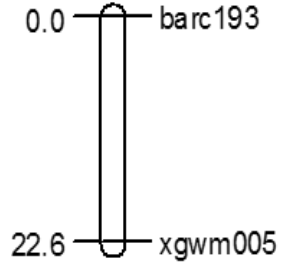

4A

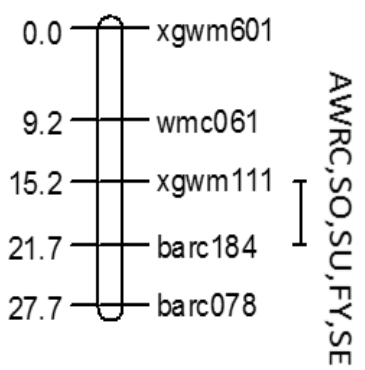

Peer] reviewing PDF | (2017:12:22370:1:1:NEW 8 Feb 2018)

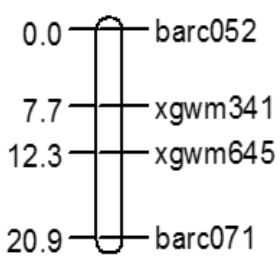

I

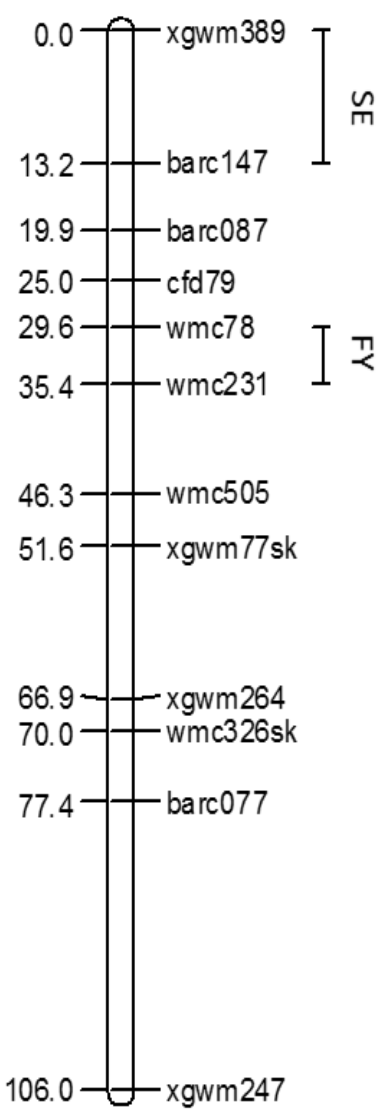

4B

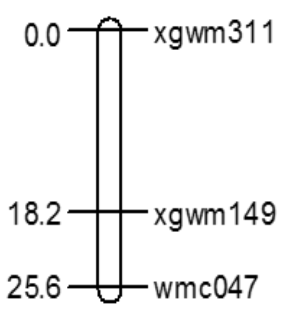

$5 A$

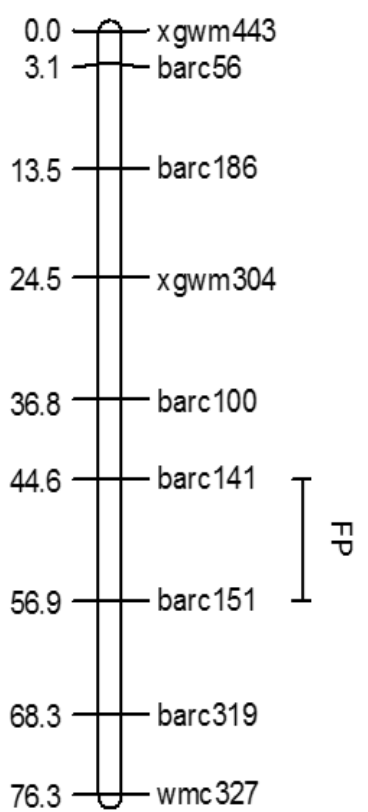


5B

PeerJ

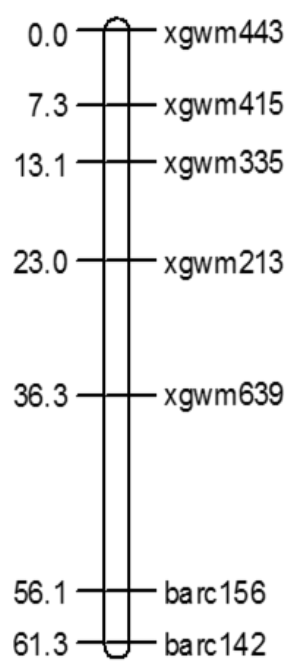

7A

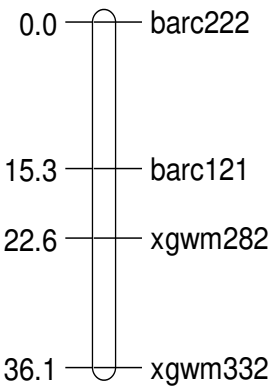

5D

6B

Manuscript to be reviewed

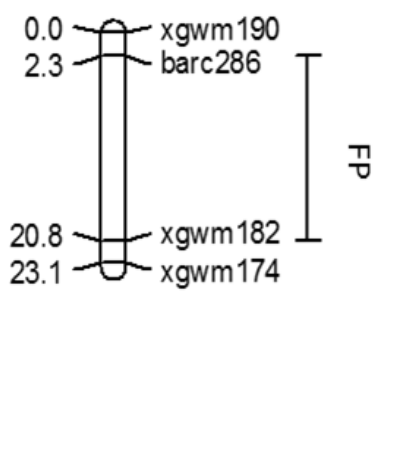

7B

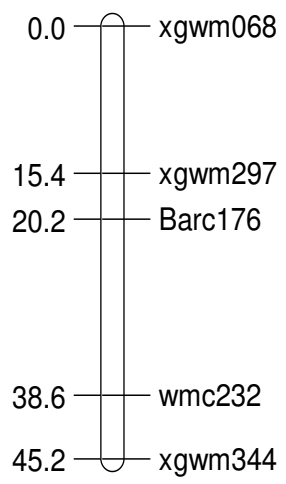

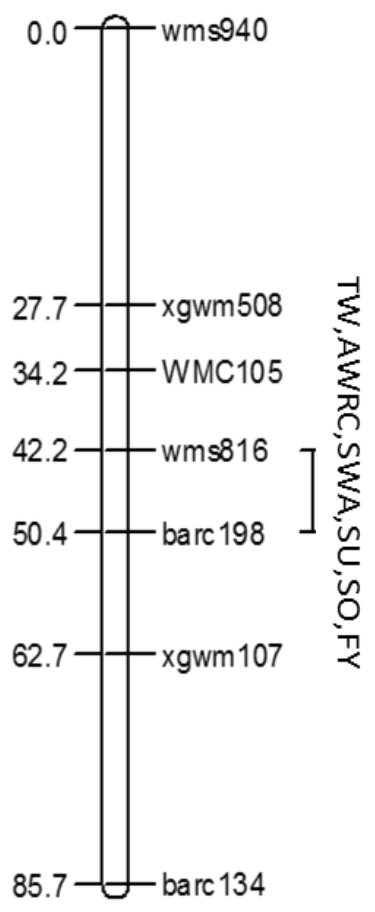

7D

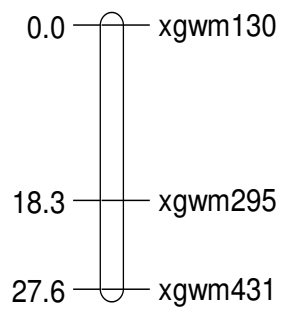

